\title{
Self-Portrait of a Lady as an Absent Latinist
}

Lucy Hutchinson and the Recording of Encounter and Loss

Autoportrait de femme en latiniste absente: Lucy Hutchinson ou le récit de la rencontre et de la perte

\section{Michael A. Soubbotnik}

\section{(2) OpenEdition}

Journals

\section{Electronic version}

URL: http://journals.openedition.org/aes/741

DOI: 10.4000/aes.741

ISSN: 2258-093X

\section{Publisher}

Laboratoire LISAA

\section{Electronic reference}

Michael A. Soubbotnik, «Self-Portrait of a Lady as an Absent Latinist », Arts et Savoirs [Online],

6 | 2016, Online since 06 July 2016, connection on 02 May 2019. URL : http://journals.openedition.org/ aes/741 ; DOI : 10.4000/aes.741

This text was automatically generated on 2 May 2019.

Centre de recherche LISAA (Littératures SAvoirs et Arts) 


\title{
Self-Portrait of a Lady as an Absent Latinist
}

\author{
Lucy Hutchinson and the Recording of Encounter and Loss \\ Autoportrait de femme en latiniste absente: Lucy Hutchinson ou le récit de la \\ rencontre et de la perte
}

Michael A. Soubbotnik

\section{An Encounter in absentia}

1 Lucy Hutchinson was born on January $29^{\text {th }} 1620$ the daughter of Sir Allen Apsley, Lieutenant of the Tower of London and his third wife Lucy, daughter of Sir John St John.

The land was then at peace (it being towards the latter end of the reign of King James), if that quietness may be called a peace which was rather like the calm and smooth surface of the sea whose dark womb is already impregnated with a horrid tempest. ${ }^{1}$

2 Her family belonged to this English puritan-leaning gentry whose economic power and (cautious) political activism in the Commons had been steadily growing since the transference to the Crown of the taxes payable to Rome in 1536 and the ensuing dissolution of monasteries which, as Lucy notes, "left" the members of her own kind, in whom she saw the bearers of the "interests of the people", "only to expect an opportunity to resume their power into their own hands". "Received with a great deal of joy" 3 by her parents who doted upon her as the first female child after three boys, she manifested such remarkable intellectual aptitudes and appetites at a very early age, that her father gave her a typically humanist education rarely bestowed on a girl : French, Italian, Latin, Greek, even a little Hebrew. At four, she "read English perfectly" and at seven, she had "at one time eight tutors in several qualities, languages, music, dancing, writing and needlework" but had a "genius quite adverse from all but [her] book" and took every opportunity to escape girly tuition or games and "steal into some hole or other to read" 
Above all else, Latin was her favorite study. At ten she was fluent in reading, writing and speaking it. It was to be one of the main passions of her life.

The great swerve in Lucy's life was her marriage for love with John Hutchinson in 1638. A puritan gentleman, John was elected to the 1640 Parliament and received a commission of Lieutenant-Colonel in the Parliamentary Army after the Civil War broke out in 1642. He was subsequently appointed Governor of Nottingham Castle then of the town as well in 1643. Lucy followed him everywhere, tending the wounded of both sides during the siege of Nottingham and discussing all political and religious ${ }^{5}$ matters with her husband who, as it appears, hardly took any significant decision without consulting her. The royalist defeat brought John back to Parliament. In January 1649, he signed King Charles' death warrant. Highly critical of the rising power of the Army over Parliament, John and Lucy broke with Cromwell for good in 1650 and retired from public life on their Nottinghamshire estates where she composed in verse the first complete English translation of the six books of Lucretius ${ }^{6}$. At the Restoration John was arrested on a charge of regicide. Lucy managed to have him freed and pardoned against his will, but in October 1663, he was accused of having taken part in a republican plot. Arrested once again, he was transferred from the Tower to the cold and damp Sandown Castle in Kent where he died of illness in September 1664. Lucy started almost immediately to write her Memoirs of the Life of Colonel Hutchinson, which she completed in 1671. This impressive masterpiece was first printed in the early $19^{\text {th }}$ century by a descendant.

This is where we find the "self-portrait" mentioned in the title. It is inserted in the narrative of John's first encounter with Lucy... in her absence. Entangled in difficult relationships with his father and stepmother, John had gone to Richmond, which was then some sort of meeting point for young courtiers, and had taken up lodgings at the house of a gentleman composer of lute music for the court. There, he befriended the nine year-old Barbara, Lucy's baby sister, who "tabled for the practice of her lute" at the same house. While John Hutchinson was arriving and settling in Richmond, Lucy was in Wiltshire with their mother who was determined to negotiate a match between her quite unenthusiastic elder daughter and some suitable local gentleman.

Barbara,

having the keys of her mother's house, some half a mile distant, would sometimes ask Mr. Hutchinson, when she went over, to walk along with her and carry him into her sister's closet and give him of the sweetmeats she had left behind her. (MH, p. 46)

The "encounter" in absentia took place on one of these occasions.

One day when Mr. Hutchinson was there, looking upon an odd by-shelf, he found a few Latin books; asking whose they were, he was told they were her elder sister's, whereupon, enquiring more after her, he began first to be sorry she was gone before he had seen her, and gone upon such an account that he was not likely to see her. (MH p. 46)

7 In the immediate aftermath of this encounter wherein the Latin books played the very same role as the portraits or medallions in romances,

he grew to love to hear mention of her, and the other gentlewomen who had been her companions used to talk much to him of her, telling how reserved and studious she was, and other things which they esteemed no advantage. But it so much enflamed Mr. Hutchinson's desire of seeing her that he began to wonder at himself, that his heart, which had ever had so much indifferency for the most excellent of woman kind, should have so strong impulses towards a stranger he never saw; and 
certainly it was of the Lord, though he perceived it not, who had ordained him, through so many various providences, to be yoked with her in whom he found so much satisfaction. There scarcely passed any day but some accident or some discourse still kept awake his desire of seeing this gentlewoman, although the mention of her, for the most part, was enquiries whether she had yet accomplished the marriage that was in treaty. (MH p. 46-47)

\section{Lucretius and God's Providences} a limited number of identifying features held by the self-portraitist to present and/or represent themself in a relevant manner. Relevance is admittedly a somewhat blurry notion here, but since it is typically a family-resemblance concept, blurry is after all what it should be. Pushing my initial assumption even further, I therefore assume it possible for a literary self-portrait to consist of one single feature, given that this feature be inserted in a proper background or set of "circumstances".

The problem I propose to start with relates Lucy's self-representation at an unparalleled moment of her (and John's) destiny, to her work as a poet and translator of Lucretius? Like everyone else I wonder how a devout puritan and committed republican like Lucy could spend so much time studying and translating a philosophical poem which not only seemed to contradict all her beliefs but was also an object of interest in royalist coteries. After the royalist defeat, a strong wave of interest in atomism swept through some Cavalier circles in Paris, in particular the one presided by William Cavendish Marquis of Newcastle, who would play an important role in promoting epicurean ideas in Restoration England. Gassendi's work on Epicurus inspired Margaret Cavendish's atomistic pieces in her 1653 Poems and Fancies 8 .

Oppositely, Lucy's rather disingenuous disavowal of her carefully wrought artwork in her famous 1675 letter to Lord Anglesey some twenty years later, should equally raise questions. "My Lord", she writes,

When I present this unworthy Translation to your Lordship, I sacrifice my shame to my obedience for though a masculine Wit hath thought it worth printing his head in a laurel crown for the version of one of these books ${ }^{9}$, I am so far from glorying in my six, that had they not by misfortune been gone out of my hands in one lost copy, even your Lordship's command, which hath more authority with me, than any human thing I pay reverence to, should not have redeemed it from the fire [...]. So I beseech your Lordship to reward my obedience, by indulging me the further honor to preserve, wherever your Lordship shall dispose this book, this record with it, that I abhor all the Atheisms and Impieties in it, and translated it only out of youthful curiosity, to understand things I heard so much discourse of at second hand, but without the least inclination to propagate any of the wicked pernicious doctrines in it. [Even] I did not employ any serious study in, for I turned it into English in a room where my children practised the several qualities they were taught with their Tutors, and I numbered the syllables of my translation by the threds of the canvas I wrought in, and set them down with a pen and ink that stood by me [...]. (L, p. 23)

Surely, the evocation of a charming family scene offers a rather lame excuse for such a translation (considering the stakes of propagating "wicked and pernicious doctrines" full of "Atheisms and Impieties") and a yet weaker plea to have a book burnt (whose malfeasance seems hardly to exceed that of needlework). Contrasting with such belittling of her own work, her annotations and the verse summaries at the head of every book, 
help the reader understand the text and discard its doctrines but very rarely. These elements were most probably added the very same year as the letter..$^{10}$ Moreover, one cannot but agree with Jonathan Goldberg ${ }^{11}$ that Lucretius' influence is pervasive in Lucy's writings, which is the main point at hand.

It is most remarkably so in the various and numerous metaphors relative to all forms of simulacra that she uses in death-related passages of the Memoirs, the Elegies ${ }^{12}$ and, last but not least, her great religious poem Order and Disorder ${ }^{13}$. But more of this later. The main point now is this: as readers of both Order and Disorder and Paradise Lost never failed to notice, Lucy, contrary to Milton, never endeavors to explain or justify God's actions in His own terms, so to speak, but is always remaining at human level. It is true, of course, that the lucretian view of divine beings totally removed from human affairs is the exact opposite of Lucy's puritan emphasis on divine providences taking "care and account of [men's] smallest concernments, even the hairs of their heads". Particular providences constitute for Lucy an extremely significant element of a person's identity: the providences in our lives combine with our "circumstances" to define us, and this they do in relation to that part of ourselves which, most of the times unbeknownst to us, will shape our lives. This is why Lucy maintains an exquisite tension between her radically transcendent god and the constant relation human individuals must maintain with this god's business in human affairs both particular and collective. But this too she meditates and reflects upon exclusively from the creature's point of view, leaving the deity as impenetrable as Lucretius' gods.

\section{The Grace of Love by the Grace of God and Death Without Simulacra}

13 Now, the Lucy/Lucretius question may be approached along more psychological lines as well. Greenblatt certainly hints at an important element when he emphasizes the sheer literary beauty of Lucretius's poem and the appeal it exerted on early modern Latinist readers ${ }^{14}$. Lucy was indeed extremely fond of poetry and more especially of classical Latin verse. Her commonplace book displays excerpts from Virgil, Ovid, Horace, etc. in the original and in translations by various authors, as well as drafts of her own translations. With her being so engrossed in Latin language and so good at it, the sheer challenge of translating Lucretius and the sumptuousness of his poetry could but help strengthen Lucy's usual drive to "see by herself" and "understand things [she] heard so much discourse of at second hand" (L, p. 23). Moreover, Latin was a very intimate part of herself in relation to this most important feeling of hers - that of being elected, first by her parents' love, particularly as manifested in their educational care, then by her husband's and hopefully, though she proclaims that there is no way to know, ultimately by God's.

With all that in mind, we may turn to what I deem, perhaps a little boldly, to be Lucy's self-portrait. Michel Beaujour insists that "the absence of a continuous narrative in the self portrait distinguishes it from the autobiography"15. This sounds both reasonable enough and a trifle too peremptory. If the mention of some distinctive feature in a relevant context can function as a self-portrait asserting some form of "here I am", why should anything forbid the relevant context to be of a narrative kind? 

"temptations" of feminine beauty, cunning and wealth. While clearing the way, so to speak, for Lucy's entrance as "the real deal", both sketches are written in the best rhetorical vein of the times as exempla of virtue, allowing for a puritan vindication of love (including physical desire) in matrimony and showing the workings of providence in bringing John and Lucy together.

[...] there was in the town a young maid, beautiful, and esteemed to be very rich, but of base parentage and penurious education, though else ingenious enough. She was the grandchild and heiress of an old physician, and from her childhood having been acquainted with Mr. Hutchinson who used to visit her grandmother, she had conceived a kindness for him, which though he civilly resented, his great heart could never stoop to think of marrying into so mean a stock; yet by reason of some liking he showed for her company, and the melancholy he had, with some discontents at home, she was willing to flatter herself it was love for her, wherein, when she discovered her mistake, it was a great grief [...]. In the house with Mr. Hutchinson, there was a young gentlewoman of such admirable tempting beauty and such excellent good nature, as would have thawed a rock of ice, yet even she could never get an acquaintance with him. Wealth and beauty thus in vain tempted him, for it was not yet his time of love; but it was not far off. (MH, p. 44)

In the first sketch, the more important teaching probably concerns what John does not see, that is the maid's love for him. This has to be contrasted to what he will see when he finally meets Lucy and engage in what initially takes the form of a close friendship, that is her love for him. Love here follows the same pattern as divine grace and election ${ }^{16}$ whose surest sign is that it is bestowed on those whose own predisposition to love enables them not to confuse God's love with anything else the world has to offer. A few lines later, Lucy wraps up the whole morality of her sketches by plunging John in the wider theater of the courtiers' society of Richmond. Note here the use of the word "snares", commonly associated with devilish doings, to give added color to this true to life allegory of "temptation resisted". And Lucy being a wit atop of a freakishly knowledgeable young woman ${ }^{17}$ may have also mocked her own mother's repeated attempts to marry her, the difference being here that she herself was responsible for the ensuing repeated failures.

$\mathrm{He}[. .$.$] went to Richmond, where he found a great deal of good young company, and$ many ingenuous persons. [...]. Mr Hutchinson was soon courted into their acquaintance, and invited to their houses, where he was nobly treated, with all the attractive arts that young women and their parents use to procure them lovers; but though some of them were very handsome, others wealthy, witty, and well qualified, and all of them set out with the gaiety and bravery that vain women put on to set themselves off, yet Mr Hutchinson could not be entangled in any of their fine snares; but without any taint of incivility, he in such a way of handsome raillery reproved their pride and vanity, as made them ashamed of their glory, and vexed that he alone, of all the young gentlemen that belonged to the court or neighbourhood, should be insensible of their charms. (MH, p. 45-46)

The second passage is more complex:

[That] day telling a gentleman of the house whither he was going [to Richmond], the gentleman bid him take heed of the place, for it was so fatal for love, that never any young disengaged person went thither, who returned again free. Mr. Hutchinson laughed at him, but he to confirm it told him a very true story of a gentleman who not long before had come for some time to lodge there, and found all the people he 
came in company with, bewailing the death of a gentlewoman that had lived there. Hearing her so much deplored, he made inquiry after her, and grew so in love with the description that no other discourse could at first please him, nor could he at last endure any other; he grew desperately melancholy, and would go to a mount where the print of her foot was cut, and lie there pining and kissing of it all the day long, till at length death, in some months' space, concluded his languishment. This story was very true; but Mr. Hutchinson was neither easy to believe it, nor frighted at the example, thinking himself not likely to make another. (MH, p. 45)

At the most obvious level, the pining lover episode ironically foreshadows John's own obsession with a very elusive Lucy and once again bears testimony of how little humans know of themselves, while God's providences lead the elect from what they unknowingly have to become to a better knowledge of what they are. But there is more than that. In the story told to John, the woman is dead. In John's story, Lucy merely is in Wiltshire but John could very well never get to meet her. Hence the scene of Lucy's practical joke. Having defused all threat of a Wiltshire marriage in ways she does not deem fit to tell in the Memoirs, Lucy, who knows that her common hostile attitude towards suitors and her mother's desperate efforts to drive her toward a consented marriage are a favored topic in Richmond, sends a servant to the house where Barbara is tabling, with instructions to make the company believe she is married and distribute "bride laces" to everyone according to the custom of the times. Whereupon

Mr. Hutchinson immediately turned pale as ashes and felt a fainting to seize his spirits in such extraordinary manner that, finding himself ready to sink at table, he was fain to pretend something had offended his stomach and to retire from the table [...]; the distemper of his mind had infected his body with a cold sweat and such a dispersion of spirits that all the courage he could at present recollect was little enough to keep him alive. [...]. When Mr. Hutchinson, being alone, began to recollect his wisdom and his reason, and to wonder at himself, why he should be so concerned in an unknown person, he then remembered the story was told him when he came down, and began to believe there was some magic in the place which enchanted men out of their right senses. But it booted him not to be angry at himself, nor to set wisdom in her reproving chair, or reason in her throne of council: the sick heart could not be chid or advised into health. [...] [H]aving fortified himself with resolution, he got up he next day, but yet could not quit himself of an extravagant perplexity of soul concerning this unknown gentlewoman, which had not been admirable in another light person but in him, who was from his childhood so serious and so rational in all his considerations, it was the effect of a miraculous power of Providence, leading him to her that was destined to make his future joy. (MH, p. 47-49)

Now, the story does not only concern Lucy's absence (prefigured by the woman's death) and John's fainting (prefigured by the gentleman's languor). As deadly languor can be an image of fainting, fainting can be an image of fading away, that is of dying. Roles are then reversed. If the story concerns John's death and absence when the Memoirs, this "imprint" of his life, were written, the gentlewoman is an image of him who is dead and the languid gentleman an image of Lucy in her grief. But there is still more. Here is what Lucy writes of their mutual love after she told the rather romantic story of their encounter:

[N] ever was there a passion more ardent and less idolatrous; he loved her better than his life, with inexpressible tenderness and kindness, had a most high obliging esteem of her [...]. And thus indeed [...] she was a very faithful mirror, reflecting truly, though but dimly, his own glories upon him, so long as he was present; but she, that was nothing before his inspection gave her a fair figure, when he was removed, was only filled with a dark mist, and never could again take in any delightful object, nor return any shining representation. The greatest excellency 
she had was the power of apprehending and the virtue of loving his. So, as his shadow, she waited on him everywhere, till he was taken into that region of light which admits of none, and then she vanished into nothing. (MH, p. 51-52)

bodies after Judgment Day, she never ventured to say anything about it, since death and the "beyond" admit of no image, therefore of no way to say it. Partings are definitive and no happy reunions of lovers beyond death are forthcoming. One could venture that both Lucy's unwavering religious refusal to have a peek at the unknowable and her profound need of John's physical presence ${ }^{18}$ combine to wipe off any trace of a representation of the afterlife from Lucy's writings. This very peculiar kind of iconoclasm is not just a vivid expression of the melancholy of grief. The fading away of simulacra has a much wider range in Lucy's own vision. In Order and Disorder she relates how Abraham's dead body was laid in the sepulcher alongside his "dear Sarah", then comments:

Death now rejoins whom death did late divide.

But none the joy of these reunions share,

For after death the tenderest loving pair

No more converse, though lodged in one cold bed;

No more embrace when sense and life are fled.

(HO 16., p. 314-318)

What remains, though, in the case of John and Lucy, is the materiality of Lucy's writing, (too) expectedly as a trace but more significantly as an act which contradicts the selfproclaimed passivity of her conventional social role. Hence the extreme importance of the Memoirs, which could very well bear the same preamble than the attempted then interrupted autobiography. They are indeed a rewriting of God's writing of the characters of his providences:

The Almighty Author of all beings in his various providences, whereby he conducts the lives of men from the cradle to the tomb, exercises no less wisdom and goodness than he manifests power and greatness in their creation; but such is the stupidity of blind mortals that, instead of employing their studies in these admirable books of providence wherein God daily exhibits to us the glorious characters of his love, kindness, wisdom and justice, they ungratefully regard them not, and call the most wonderful operations of the great God the common accidents of human life, especially if they be such as are usual [...]; for in things great and extraordinary, some, perhaps, will take notice of God's working who either forget or believe not that he takes as well a care and account of their smallest concernments, even the hairs of their heads. (MH 3) 


\section{Hypothetical Conclusions}

24 various lines of thought and feeling. Firstly, we may consider Lucy's tendency to emphasize the love she inspires and reciprocates as an identifying feature. The love of her parents who had Latin and humanities in general taught to her and the love of John Hutchinson who scorned beauty and wealth and fell for her after seeing her Latin books. Secondly, the series of God's providences who guide John to Richmond, then to her house, then to her chamber where he eventually spots the "odd bookshelf" do not only "yoke" Lucy and John together and commit them both to the Good Old Cause of Parliament and congregationalism. They also contribute to define each one of them as a person under the unfathomable discretion of a transcendent God.

The relation between the first and the second element is above all textual. As has been shown, the images and narratives of marital love, as opposed to flimsy and insignificant affections, are encased in passages on loss and death. As much as Lucy's metaphors bear witness to the influence of the lucretian theory of images (simulacra), the narrative and autobiographic sketches hint at what remains after shadows and reflections of beautiful objects faded into nothingness. What remains is the double writing of God's providences and of the creatures' memorials. Of Lucretius, nothing remains but his poem, noted Lucy. of John and the mirror she handed to him, nothing remains but the translation "of the six" that she wrote during a politically disappointing but privately fulfilling period, the Elegies, the sumptuous Memoirs and the great poem Order and Disorder. Writing is where this paradox of the author's quasi omnipresence in her very elusiveness qua widow can be expressed as the truest "here I am and there I am not" at the core of Lucy's identity as a living and surviving person.

\section{NOTES}

1. Lucy Hutchinson, "Fragment of autobiography", in Memoirs of the life of colonel Hutchinson, with a fragment of autobiography, N. H. Keeble ed., London, Dent, 1995 (Thereafter FA), p. 4.

2. Lucy Hutchinson, Memoirs of the life of colonel Hutchinson, with a fragment of autobiography, edited by N. H. Keeble, London, Dent, 1995 (Thereafter MH), p. 61. Here is the whole passage. Lucy's republicanism considerably radicalizes the interests of her own class: "The interest of the people, which had been many years growing, made an extraordinary progress in the days of King Henry the Eighth, who, returning the vast revenues of the church into the body of the people, cast the balance clear on their side and left them now only to expect an opportunity to resume their power into their own hands, which, had not the different interests of religion divided them among themselves and thereby prolonged the last gasps of expiring monarchy, they had long since exercised it in a free commonwealth ».

3. FA, p. 4.

4. FA, p. 14. 
5. She most probably convinced her husband to embrace her Baptist creed, a rather dramatic step at the time.

6. Lucy's faircopied manuscript verse translation antecedes the first printed (almost) complete one by Thomas Creech in 1682.

7. Lucy Apsley Hutchinson, Lucy Hutchinson's Translation of Lucretius De Rerum Natura, edited with introduction and commentary by Hugh de Quehen, London, Duckworth, 1996 (thereafter L).

8. Margaret Marquess of Newcastle, Poems and Fancies, London, J. Martin and J. Allestrye, 1653. The first part of the collection is a series of atomistic didactic poems. After an allegoric opening showing how "Nature calls a Councell, which was Motion, Figure, matter, and Life, to advise about making the World" and "Deaths endeavour to hinder, and obstruct Nature", the first poem bears the title "A World made by Atomes".

9. John Evelyn, whose translation of Book I of Lucretius was published in 1656. In his introduction, Hugh de Quehen provides a very interesting comparative study of Lucy Hutchinson's translation with other verse renditions, complete or partial, down to Dryden's.

10. See Jonathan Goldberg, "Lucy Hutchinson Writing Matter", ELH, vol. 37, no 1, 2006, p. 279.

11. For a very detailed analysis of Lucretius' presence in various writings by Lucy Hutchinson, see Jonathan Goldberg, op. cit., passim.

12. Lucy Apsley Hutchinson, "Lucy Hutchinson's 'Elegies' (Nottinghamshire Archives, DD/HU2)” in Jill Seal Millman \& Gilian Wright eds., Early modern women's manuscript poetry, Manchester, New York, Manchester University Press, 2005, p. 97-110.

13. Lucy Apsley Hutchinson, Order and Disorder, David Norbrook ed., Oxford, Blackwell, 2001 (thereafter OD).

14. See Stephen Greenblatt, The Swerve. How the World Became Modern, New York, Norton, 2011, p. 256.

15. Michel Beaujour, Poetics of the Literary Self-Portrait, transl. Yara Milos, New York, New York University Press, 1991, p. 2.

16. Easy enough, given that the Augustinian view construes the whole history of nature and grace more or less on the model of a love affair.

17. This explains, along with her good looks, why Lucy was relentlessly being courted (in vain) by young gentlemen who, according to the standards of the times, should have been deterred by her bookish tastes.

18. As shown by her relentless efforts to be authorized to spend nights with her husband in his ultimate gloomy and fatally uncomfortable place of detention.

\section{ABSTRACTS}

In The Memoirs of Colonel Hutchinson, Lucy Hutchinson not only built a vibrant vindication of her late beloved husband, but also wrote an impressive account of the English Civil War. The genre demanded that this remarkably talented and knowledgeable woman remain self-effaced behind the man she praised. Here we find her, however, as much self-enhanced as self-effaced in the guise of the great latinist she was, author of the first complete translation of Lucretius in verse.

Dans les Mémoires du Colonel Hutchinson, Lucy Hutchinson non seulement construit une vibrante défense de la mémoire du mari bien-aimé mais encore une impressionnante histoire de la Guerre Civile Anglaise. Le genre exigeait de cette femme au savoir et au talent hors du commun qu'elle 
s'effaçât derrière l'homme dont elle dressait l'éloge. La voici pourtant, tout autant glorifiée qu'effacée sous l'aspect de la grande latiniste qu'elle fut, auteure de la première traduction complète de Lucrèce en vers.

\section{AUTHOR}

MICHAEL A. SOUBBOTNIK 